\title{
Bioefficacy of neonicotinoid insecticide as seed treatment against early sucking pests of soybean crop
}

\author{
S.K. MISHRA*, VIKAS GUPTA AND R.K. SARAF
}

Dryland Horticulture Research and Training Centre, Jawaharlal Nehru Krishi Vishwa Vidyalaya, Garhakota, SAGAR (M.P.) INDIA

\section{ARITCLE INFO}

Received : 05.07 .2017

Revised : 10.08 .2017

Accepted : 22.08.2017

\section{KEY WORDS :}

Bioefficacy, Neonicotinoid, Imidacloprid, Thiamethoxam, Sucking pests, Seed treatment, Soybean

*Corresponding author: Email : mishradhrtc@gmail.com

\begin{abstract}
A field experiment was conducted at JNKVV, DHRTC farm during 2014 and 2015 to evaluate the effectiveness of imidacloprid and Thiamethoxam, used as seed treatment against the sucking pests of soybean crop. In this experiment numbers of sucking pests were counted at seven days interval starting from 20 days of sowing till five weeks after first observation. The number of jassids and white flies were counted from top three and two middle leaves of randomly selected 5 plants in each plot. The whitefly population was comparatively higher than that of jassids. The overall effect of insecticidal treatments at all the six intervals on sucking pest population revealed that all the treatments were found effective in comparison to untreated check. The treatment of Imidacloprid600 FS @ 1.50 g. a.i. / kg seed followed by Imidacloprid600 FS @ 0.75 g. a.i. $/ \mathrm{kg}$ seed was found most effective against the early sucking pests on soybean. The treatment of Thiamethoxom 70\% WS @ 2g/kg seed was least effective against the sucking pests. All the insecticidal treatments increased the yield of soybean seed significantly over the control. The highest seed yield was obtained from the treatment of imidacloprid600 FS @ 1.50 g. a.i. $/ \mathrm{kg}$ seed.
\end{abstract}

How to view point the article : Mishra, S.K., Gupta, Vikas and Saraf, R.K. (2017). Bioefficacy of neonicotinoid insecticide as seed treatment against early sucking pests of soybean crop. Internat. J. Plant Protec., 10(2) : 275-280, DOI : 10.15740/HAS/IJPP/10.2/275-280. 